\title{
Ensuring Performance - A Permanent Challenge for Public Sector Organizations
}

\author{
Maria-Cristina Ștefan $^{1}$, Alina Gabriela Brezoi ${ }^{2 *}$ \\ *Valahia University of Targoviste, No. 2 Carol I Bd., Dambovita, Romania \\ e-mail: crys07stefan@yahoo.com \\ ** Faculty of Economic Sciences, Petroleum-Gas University of Ploieşti, PhD Student at Valahia \\ University of Targoviste, No. 2 Carol I Bd., Dambovita, Romania \\ e-mail: alina_brezoi@yahoo.com
}

DOI: 10.51865/EITC.2021.03.09

\begin{abstract}
Organizational performance is one of the most important topics in specialized research and can be considered the most important indicator of an organization's success. Performance in the enterprise expresses not only the decrease of the cost-value pair, but everything that brings to the fore its efficiency and effectiveness, materialized in indicators. Performance management is a specialized form of general management that focuses on increasing performance in the organization, a process based on a specific system of principles and rules, methods, techniques and tools.
\end{abstract}

Keywords: strategic performance management; balanced dashboard proposal; measuring the performance of a public organization.

JEL Classification: $H 11 ; P 47$.

\section{Introduction}

The term performance comes from the English noun "performance", whose definition offered by the Oxford Advanced Learner's Dictionary is part of a double perspective. According to the description, performance is equal to the level of how well or how little good an activity is performed / functions or the actual action that leads to the performance of an action / task, meaning attributed to the English verb "to perform". If we refer to the Explanatory Dictionary of the Romanian language, performance makes sense of result / achievement, moreover, the term is not associated with a verb, which can lead to error in its use with other neologism terms, for example, "management".

\section{Representative Aspects regarding Performance Management}

Performance management includes all processes and activities that ensure that the achievement of strategic objectives is consistent in the most effective and efficient manner in terms of

\footnotetext{
${ }^{*}$ Corresponding author
} 
balance of power and the time horizon in which the needs of actors can be met or not create risks “( (Popa, 2005 ).

M. Armstrong (2009) identifies performance management as: "the process of systematically improving the organization's performance by developing the individual performance of employees and work teams", supporting the idea of aligning individual objectives with the organization's objectives to ensure performance. The purpose of this process is to establish a culture of performance, in which individuals / actors take responsibility for continuously improving their own processes and skills, to achieve the product / service in accordance with customer requirements and expectations.

\section{The strategic performance management}

Strategic performance management is presented as: "process in which the management of the organization is achieved by systematically defining the mission, strategy and objectives of the organization, values quantified through success factors and key performance indicators, in order to perform corrective actions to improve to keep the organization on track" (De Waal, 2006). Strategic performance management pursues a number of objectives and goals:

o supports and develops individual and organizational learning;

o justifies the investment process;

o supports the planning of organizational activities;

o sustainably improves performance in the organization;

o develops benchmarks;

o develops constructive relationships between employees and managers through a process of continuous dialogue;

o increases the development of team cohesion and performance;

o increases job satisfaction and helps to achieve one's own and the organization's benefit.

\section{The Dutch approach}

According to Dutch professor André A. de Waal, the strategic performance management process consists of the following major sub-processes (Figure 1):

o Strategy development. The strategic objectives are clearly determined and formulated and the action plans are drawn up. Strategic plans must provide realistic long-term perspectives and how to achieve the set goals.

o Setting the budget and strategic targets. The process results in short-term operational action plans to achieve/improve strategic targets creating financial resources/added value.

o Execution / forecasting. The activities leading to the specific results established above are implemented. The forecast must be made regularly to predict whether the organization is following the desired course and / or preventive / corrective improvement actions are needed.

o Measuring the level of performance. Data and information necessary for the efficient execution of organizational processes are collected, processed and distributed. The information is presented in the form of Critical Success Factors (CSFs) and Key Performance Indicators (KPIs).

o Performance evaluation. This process is performed periodically to verify the actual performance of the organization, compliance with general objectives and future forecasts. This ensures that prevention and improvement actions are carried out in a timely and efficient manner. The analysis of the previous period is essential to learn from mistakes and incorrect assessments.

o Reward incentives. There is a correlation between the level of achievement of objectives and strategic plans with the policy and the way of rewarding. The performance behavior of the members of the organization must be aligned with the other threads and rewarded according to the expectations of individuals. . 


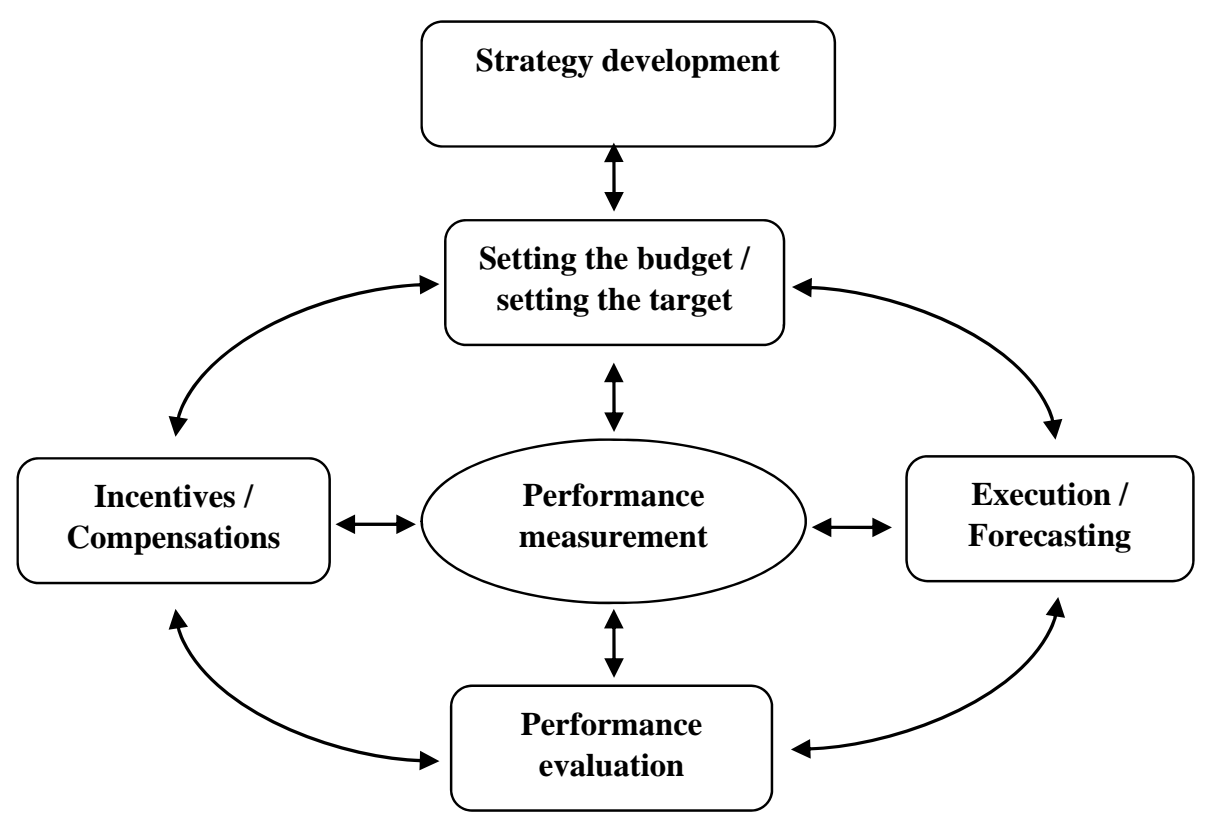

Fig. 1. Sub-processes of the strategic performance management process

Source : De Waall, 2007.

\section{The Norton-Kaplan approach}

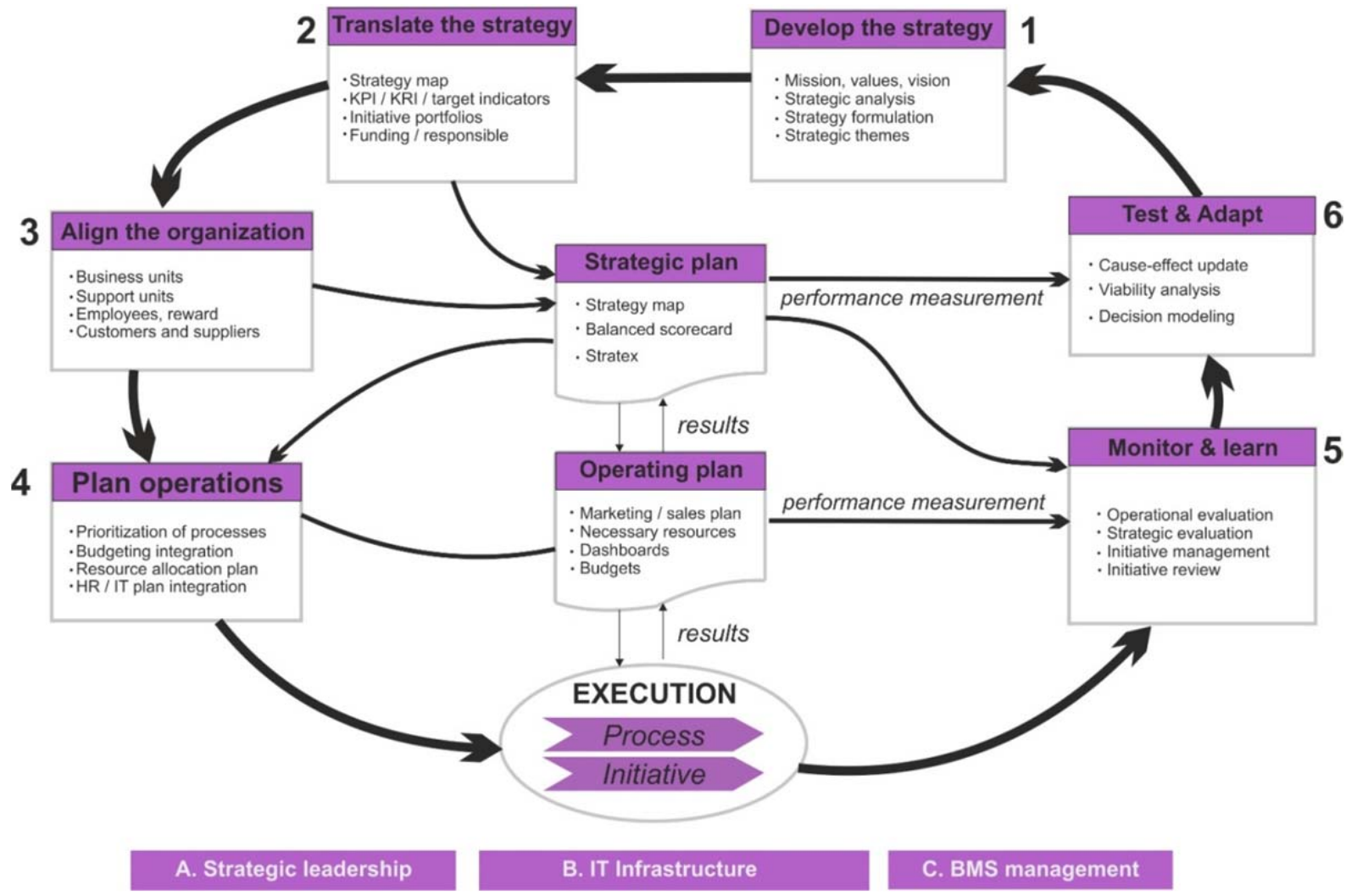

Fig. 2. Balanced Dashboard Proposal Management System

Source: Kaplan \& Norton, 2008. 
The strategic performance management system proposed by R. Kaplan and D. Norton in 1992 is a framework for measuring organizational performance using, in addition to short-term financial performance, a more balanced set of non-financial performance criteria. The authors state that: "financial measures elucidate past events, an appropriate approach for companies in the industrial period for which long-term investments and customer relations were not essential for success, to guide and develop companies in the information age must produce value future through investments in customers, suppliers, employees, processes and innovation“.

The system has evolved over the years and is now considered a fully integrated strategic management system, developed in 6 stages and 27 sub-stages (Figure 2).

\section{Implementation Methodology of Balanced Dashboard Proposal}

The implementation methodology of Balanced Dashboard Proposal (http://bscromania.wordpress.com/category/0-concepte-fundamentale/0-1-metodologia-deimplementare/.):

I. Determining change through executive leadership. Strategy in essence means change. In order to achieve a superior result, it is necessary to establish what is necessary to change the definition in the activity we carry out and generate value for customers, shareholders or partners.

01. Obtaining the support of the decision maker (GM, CEO, etc.). The execution of the new strategy will meet with resistance, so it is necessary to support the person with supreme decision-making power in the organization to implement the system.

02. Clarification of the reasons for making the change. Highlight as clearly as possible what is not working properly or the unsatisfactory results.

03. Involvement of the management team. Formulation and execution of the strategy is a complicated process, teamwork is very important.

04. Clarifying the business vision and strategy. The gap between the current direction of development of the organization and the desired / superior allows the definition of vision and strategy.

05. Confirmation of the understanding of the new management model. Implementing the TBE system can be laborious and difficult. It is necessary to explain and communicate clearly the philosophy, principles, how to define, implement, measure and manage initiatives, indicators and organizational alignment.

06. Identification of the project manager. The implementation of the TBE system is a project that will significantly influence the organization, with a specific duration and a very precise plan..

II. Translating the strategy into operational terms. The strategy must be translated into strategic and performance-enhancing objectives, targets and initiatives.

07. Structuring the Strategy and constructing the Strategic Map. The Strategic Map is the tool through which the Strategic Objectives are defined and causally related grouped in horizontally figured Perspectives (Ex. Financial, Clients, Stakeholders, Processes, etc.) or Strategic Themes, figured vertically.

08. Description of the strategy through Dashboard and indicators. Define to be able to measure, measure to be able to manage.

09. Setting targets for each Performance Indicator. Each target is associated with a specific indicator as a benchmark in achieving that target. 
10. Defining and streamlining Strategic Initiatives. Achieving strategic objectives requires a set of actions grouped into projects of strategic importance called Strategic Initiatives.

11. Obtaining the sponsorship of the management team for Initiatives. Initiative-specific budgets are introduced, which must be protected when making cost reductions when planning the organization's annual budget..

III. Aligning the organization to strategy. The execution of the strategy must be performed by the entire organization, respectively at the level of operational and support departments, work teams and each employee, as well as with the participation of stakeholders (partners, customers, suppliers, etc.).

12. Identifying the contribution of departments to the execution of the strategy. The strategy can be achieved through organizational alignment, convergent and synchronized participation of the entire organization in achieving the objectives. The alignment of operational departments and support departments is done by defining for each of them, the same set of tools that translate the strategy in operational terms: Map of Objectives, Dashboard, Targets and Performance Indicators, as well as the portfolio of Initiatives through progress / cascading.

13. Vertical alignment of operational departments. Depending on the degree of similarity of the business processes of the organizational departments, the identical, reduced or contributory cascade is achieved.

14. Horizontal alignment of support departments. The parameters of the Dashboard are cascaded from the operational units to the support ones, adequately correlating the support provided for the operational activities.

15. External alignment. The involvement of the organization in its value chain creates dependencies and correlations that can significantly influence the achievement of strategy and performance. It is necessary to align externally with the stakeholders with whom the organization is in relations (suppliers, partners, investors, regulators and customers).

16. Reporting of TBE to shareholders. The implementation of the management system through TBE includes the installation or use of an IT system that will manage and report to the top shareholders / management the strategy execution activity.

IV. Motivation and learning. Employees must understand the strategic approach, their role and participate in its execution, carrying out strategic initiatives that allow the improvement of processes to facilitate the achievement of organizational objectives.

17. Achieving a high level of understanding of the strategy. It is done through organizational communication, to allow each employee to understand the changes that have occurred and the roles assigned to each.

18. Alignment at the individual level. Alignment at the individual level is achieved through the individual Dashboard, resulting from the TB cascade of the team / department.

19. Align the individual rewards system. For the most efficient interest of the employees in the execution of the strategy, the reward system is aligned with the strategy. The level of reward is correlated with the achievement of individual TB objectives and the contribution to the development of operational action plans.

20. Aligning the skills development system. The degree of availability of human capital to meet the need for strategic jobs is analyzed.

V. Adaptation - strategy is a continuous process. The TBE system involves the correlation of the descriptive component with the prescriptive one, becoming an integrated management system for the execution of the strategy and organizational performance. 
21. Development of the TBE reporting system. The reporting system provides the necessary information for the strategic analysis sessions of the results of the organization and the component units through the prism of the performance indicators and the situation of the strategic initiatives.

22. Conducting strategic analysis meetings. The operational analysis sessions, with daily or weekly frequency, are oriented on the evaluation and analysis of the operational and tactical activity. Thus, external and internal influencing factors lead to the need to change the organization's strategy.

23. Integrate strategy with financial planning and budget. There are TBE models, in which the integration between strategic and operational plans is completely omitted. Kaplan and Norton emphasize the importance of this integration. This allows for budgetary rationalization on strategic principles and the elimination / reduction of budgeted positions that cannot be strategically aligned.

24. Align HR and IT plans with strategy. The alignment of these functions to the strategy focuses on ensuring the availability of human and IT resources, in order to achieve the strategic objectives of the organization, the results are presented in the Report on the Availability of Human Capital and IT Resources.

25. Aligning process management with strategy. The organization's operational plans, which include the marketing, production, sales, research and development plan, etc. they must be aligned and integrated with the strategic plan. This process allows the rationalization of operational processes and their strategic convergence.

26. Adaptation of the strategy and management system of the strategy execution. On a semi-annual or annual basis, the analysis of the viability and opportunity of the strategy takes place, taking into account the changes that take place in the external and internal environment of the organization. It also examines the degree of execution of the strategy, the development of strategic initiatives and the impact on the organization.

27. Office for Strategy Management. The methodology for implementing TBE ends with the presentation of the organizational management function, the strategy execution process, which is the Office for Strategy Management (BMS) or Office for Strategy Management (OSM).

\section{Public Sector Performance}

The development of strategic management in the public sector is a constantly changing need for time and the environment. Modern public administration can no longer function on the basis of traditional bureaucratic principles and requires substantial changes influenced by a number of external pressures of various kinds:

o extending and modifying the role of the public organization on new activities (consumer protection, environmental protection, etc.);

o budgetary constraints and the need to seek additional financial sources;

o the impact of information technology development;

o the factor of globalization, international standards are becoming more influential;

o changing the profile of the citizen, more aware of his rights and tempted to compare the cost / benefit ratio offered by private organizations.

Performance in the public sector describes the results of a specific activity or the aggregated results from several areas of activity of the public body, expressed in absolute terms or in relation to the results of previous periods (Handler, Koebel, Reiss and Schratzenstaller, 2004). Profiroiu (2001, p.8) defines performance in the public sector as (Figure 3): the result of the simultaneous execution of efficiency, effectiveness and adequate budgeting. 
Measuring the performance of a public organization must take into account a multitude of elements such as: effectiveness, efficiency, financial performance, quality of services, compliance with responsibilities to society and the environment, which prevents the construction and existence of a single evaluation framework.

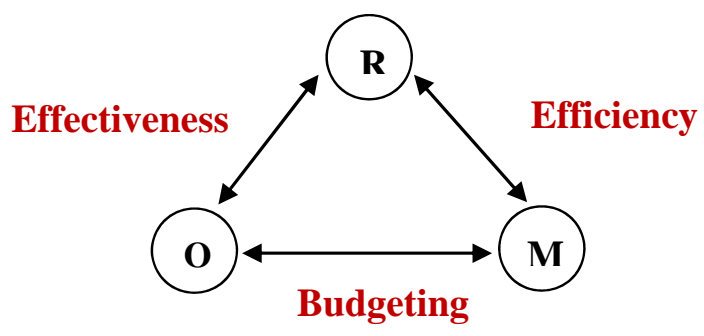

Fig. 3. Performance triangle

Source: Profiroiu, 2001.

\section{The need and timeliness of public sector performance indicators}

The system of performance indicators makes it possible to evaluate the consumption of resources in relation to the results obtained from the processes of realization / provision of services and their comparison with the levels established as objectives (Plumb, Androniceanu, Abaluta, 2003, p. 525). The system has a special practical utility, for the following reasons:

o elucidates the real situation of public services by fields;

o allows the identification of malfunctions in the process of realization / provision of the service;

o increases the collaboration with the beneficiaries of the services;

o favors the transparency of activities;

o allows the improvement of operational processes;

o correlates personal effort with results and level of performance.

The company influences the stakeholders' behavior in order to improve their well-being, preventing accidents, helping the society, protecting the environment in order to improve the quality of life. (Kotler and, Lee, 2008).

\section{The system of performance indicators applicable to public services}

The process of determining the performance indicators applicable to public services is a complex one, due to the fact that public services are located somewhere on the border between competitive logic and social logic, between which it is necessary to obtain a balance (Plumb, Androniceanu, Abaluta, 2003, p. 527). In general, performance indicators for public services fall into two categories:

o Economic indicators:

a) The cost of the service;

b) Service tariff: Ex. the price of providing the service (water, energy, etc.);

c) Efficiency of monopoly services: Ex. water network efficiency;

o Quality indicators :

a) Technical indicators: no. of transported persons, no. km street lighting, no. of applications received for the granting of social aid, water pressure, natural gas network pressure, etc.

b) Environmental indicators: degree of noise / chemical pollution, degree of pollutant loading, volume of household waste, tons of selected waste, etc.

c) Specific quality indicators: the degree of purity of drinking water, the temperature of hot water supplied to the customer, the degree of comfort in public transport, etc. 
d) Indicators of customer service: program hours, waiting time for service, level of training of graduates of vocational training institutions etc.

\section{Case Study: Performance Management of the Municipality Orhei by Implementing the Balanced Dashboard}

The city of Orhei is located in the center of the Republic of Moldova, with a number of about 37 thousand inhabitants. The population registers a recessive dynamics in the last 12-15 years of about $10.4 \%$. The city's infrastructure includes $94 \mathrm{~km}$ of streets, $160.9 \mathrm{~km}$ of drinking water network and a share of $65-70 \%$ of households adjusted to water treatment facilities. The housing stock represents about 700 thousand $\mathrm{m}^{2}$. The education system, middle school and high school, includes about 3461 students from 7 institutions (3 gymnasiums and 4 high schools). The economic sector is represented by about 609 economic agents, $1 / 4$ natural and $3 / 4$ legal persons. The industrial sector is a priority branch of the economy re-represented by 19 industrial enterprises specialized in: food (canned food, juices, dairy, bakery), cigarettes, alcoholic and soft drinks, household goods, haberdashery, footwear. The services sector is represented by about 140 enterprises. The budgetary dynamics are characterized by an average annual increase of revenues by about $8 \%$, in terms of increasing own revenues and revenues from local taxes and reducing transfers. Budget expenditures are dominated by education expenditures, with a growth dynamics of about 3\% per year and urban development through land use and infrastructure. Orhei City Hall is subordinated to 6 enterprises that perform services in the public interest and have a relative degree of autonomy. These are: S.A. RegiaApa-Canal Orhei; Î.M. Communal-Housing Services Orhei; IM. Procurement, Trade and Markets; Orhei Transport; Î.M. Hotel Codru; Î.M. Orhei Project.

\section{Balanced Dashboard Proposal}

International practices and experiences in various fields, both private and public, have demonstrated that the management system through TBE is a true model of management and management of organizational performance. The main change of the classic TBE model is to bring to the fore the customer / citizen perspective, as the main objective. In order to make the TBE elaboration process more efficient, we propose to identify several strategic themes that correlate and lead the organization's actions. Next, we outlined the strategic development themes for Orhei City Hall, the Strategic Map and the Balanced Scorecard, developed in correlation with the objectives of the City Development Strategy for the period 2014-2020.

Mission: Consolidate and increase the quality of life by modernizing neighborhoods and housing. 


\section{Community welfare}

Mission: Consolidate and increase the quality of life by modernizing neighborhoods and housing stock

\section{Restructuring the Government}

Mission: Ensuring process excellence to provide quality public services at competitive prices

\section{Economic development}

Mission: Creating and developing an attractive business environment for citizens and enterprises

\section{Transport and mobility}

Mission: To develop a safe and balanced transport infrastructure and system with the needs of the community

\section{Environmental impact}

Mission: Sustainable environmental management through waste management and the use of renewable energy resources

Fig. 4. Strategic development themes proposed for Orhei City Hall

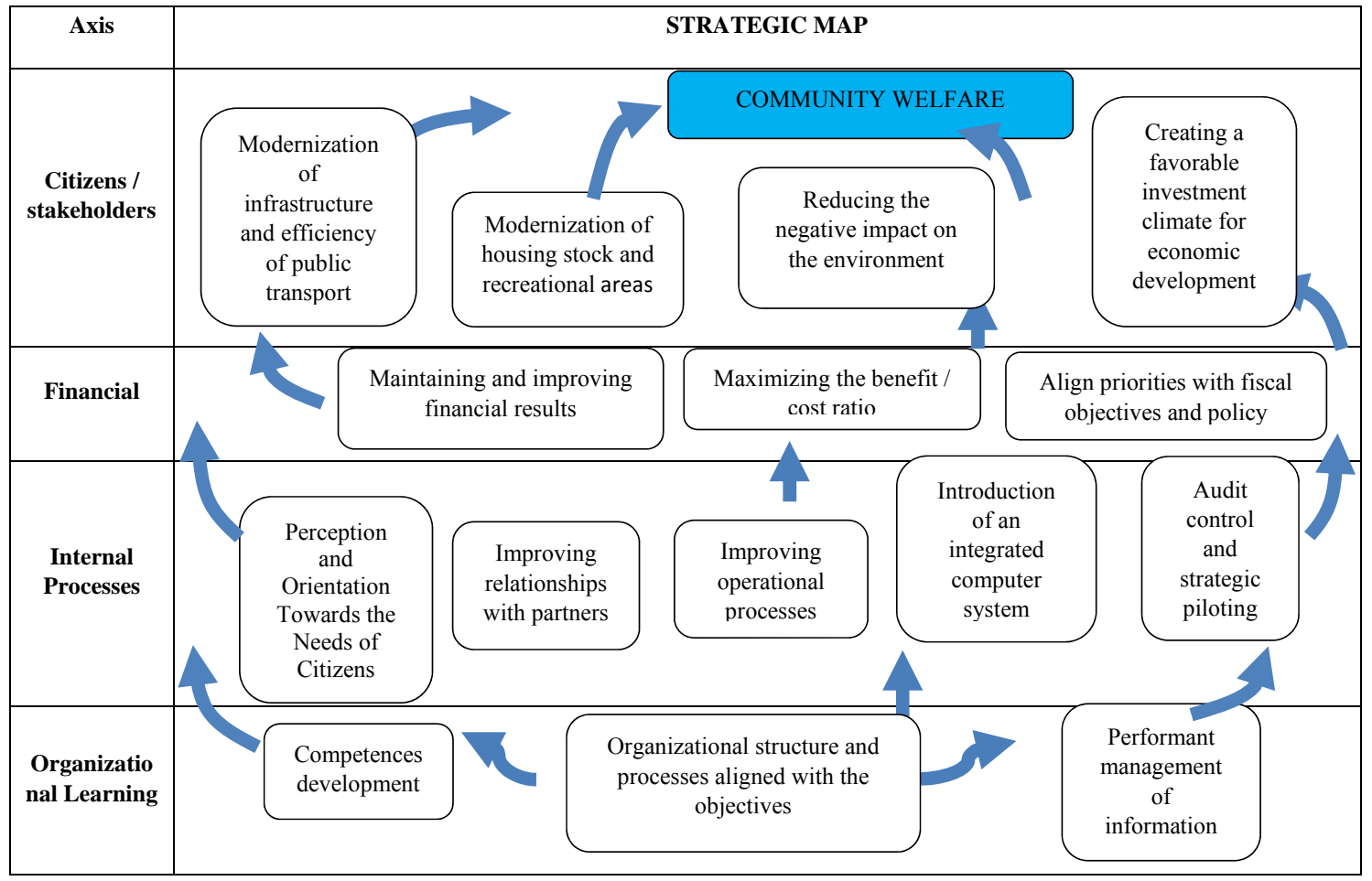

Fig. 5. Project: Strategic Map - Corporate Scorecard Orhei Municipality City Hall 
Table 1. Project: Balanced Scorecard - Balanced Scorecard Orhei Municipality City Hall 2018-2023

\begin{tabular}{|c|c|c|c|c|c|c|c|c|c|c|}
\hline \multirow{2}{*}{ Axis } & \multirow{2}{*}{ Objectives } & \multirow{2}{*}{$\begin{array}{c}\text { Objective } \\
\text { prominence }\end{array}$} & \multirow{2}{*}{$\begin{array}{l}\text { Analytical } \\
\text { hierarchy }\end{array}$} & \multicolumn{5}{|c|}{ Scorecard } & \multicolumn{2}{|c|}{$\begin{array}{l}\text { Weighted } \\
\text { score }\end{array}$} \\
\hline & & & & $0 \%$ & $25 \%$ & $50 \%$ & $75 \%$ & $100 \%$ & $\begin{array}{c}2018 \\
(1)\end{array}$ & $\begin{array}{c}2023 \\
(2)\end{array}$ \\
\hline \multirow{10}{*}{$\begin{array}{c}\text { Citizens' }^{\prime} \\
\text { Perspective / } \\
\text { stakeholder } \\
(350)\end{array}$} & $\begin{array}{l}\text { Modernization of the } \\
\text { housing stock }\end{array}$ & 120 & 42 & & & & 1 & 2 & 31.5 & 42 \\
\hline & $\begin{array}{l}\text { Fitting recreation and } \\
\text { recreation areas }\end{array}$ & 80 & 28 & & & & 1 & 2 & 21 & 28 \\
\hline & $\begin{array}{c}\text { Modernization and } \\
\text { efficiency of public } \\
\text { transport }\end{array}$ & 180 & 63 & & & 1 & 2 & & 31.5 & 47.25 \\
\hline & $\begin{array}{l}\text { Infrastructure } \\
\text { modernization }\end{array}$ & 150 & 52.5 & & & & 1 & 2 & 39.38 & 52.5 \\
\hline & $\begin{array}{l}\text { Promoting alternative } \\
\text { means of transport }\end{array}$ & 50 & 17.5 & 1 & 2 & & & & 0 & 4.38 \\
\hline & $\begin{array}{c}\text { Reducing } \\
\text { environmental } \\
\text { pollution } \\
\end{array}$ & 120 & 42 & & 1 & 2 & & & 10.5 & 21 \\
\hline & $\begin{array}{l}\text { Use of renewable } \\
\text { energy resources }\end{array}$ & 70 & 24.5 & 1 & 2 & & & & 0 & 6.12 \\
\hline & $\begin{array}{l}\text { Creating a favorable } \\
\text { investment climate }\end{array}$ & 50 & 17.5 & & 1 & 2 & & & 4.37 & 8.75 \\
\hline & $\begin{array}{c}\text { Promoting and } \\
\text { supporting SMEs }\end{array}$ & 100 & 35 & & 1 & 2 & & & 8.75 & 17.5 \\
\hline & $\begin{array}{l}\text { Capitalizing on the } \\
\text { existing tourist } \\
\text { potential }\end{array}$ & 80 & 28 & & 1 & 2 & & & 7 & 14 \\
\hline & & & & & & & & & 154 & 241.5 \\
\hline \multirow{4}{*}{$\begin{array}{c}\text { Financial } \\
\text { Perspective } \\
\quad(250)\end{array}$} & $\begin{array}{c}\text { Maximizing the } \\
\text { benefit / cost ratio }\end{array}$ & 400 & 100 & & & 1 & 2 & & 50 & 75 \\
\hline & $\begin{array}{l}\text { Maintaining and } \\
\text { improving financial } \\
\text { results }\end{array}$ & 300 & 75 & & & & 1 & 2 & 56.25 & 75 \\
\hline & $\begin{array}{l}\text { Align of priorities with } \\
\text { objectives and fiscal } \\
\text { policy }\end{array}$ & 300 & 75 & & & & 1 & 2 & 56.25 & 75 \\
\hline & & & & & & & & & 187.5 & 250 \\
\hline \multirow{6}{*}{$\begin{array}{c}\text { Internal } \\
\text { Processes } \\
\text { Perspective } \\
\text { (200) }\end{array}$} & $\begin{array}{c}\text { Perception and } \\
\text { orientation towards the } \\
\text { needs of citizens }\end{array}$ & 300 & 60 & & 1 & 2 & & & 15 & 30 \\
\hline & $\begin{array}{c}\text { Improving operational } \\
\text { processes }\end{array}$ & 250 & 50 & & & 1 & 2 & & 25 & 37.5 \\
\hline & $\begin{array}{c}\text { Introduction of an } \\
\text { integrated computer } \\
\text { system }\end{array}$ & 150 & 30 & 1 & 2 & & & & 0 & 7.5 \\
\hline & $\begin{array}{c}\text { Improving } \\
\text { relationships with } \\
\text { partners }\end{array}$ & 200 & 40 & & & 1 & 2 & & 20 & 30 \\
\hline & $\begin{array}{c}\text { Audit control and } \\
\text { monitoring of } \\
\text { achievement of } \\
\text { objectives }\end{array}$ & 100 & 20 & & & & 1 & 2 & 15 & 20 \\
\hline & & & & & & & & & 75 & 125 \\
\hline \multirow{4}{*}{$\begin{array}{c}\text { Organizational } \\
\text { Learning } \\
\text { Perspective } \\
\text { (200) }\end{array}$} & $\begin{array}{l}\text { Competences } \\
\text { development }\end{array}$ & 250 & 50 & & & 1 & 2 & & 25 & 37.5 \\
\hline & $\begin{array}{c}\text { Organizational } \\
\text { structure and processes } \\
\text { aligned with the } \\
\text { objectives }\end{array}$ & 400 & 80 & & 1 & 2 & & & 20 & 40 \\
\hline & $\begin{array}{c}\text { Performance } \\
\text { management of } \\
\text { information }\end{array}$ & 350 & 70 & & 1 & 2 & & & 17.5 & 35 \\
\hline & & & & & & & & & 62.5 & 112.5 \\
\hline $\begin{array}{c}\text { Overall value } \\
\text { of } \\
\text { performance }\end{array}$ & & & 1000 & & & & & & 479 & 729 \\
\hline
\end{tabular}


The approach of the Balanced Dashboard Proposal project is initiated with the setting of strategic objectives in line with the proposed development themes. Subsequently, according to the benchmarking methodology, the level of performance of the organization was analyzed, the general value of performance is expressed by a score of 479 points. Thus, according to table 6 , in order to improve the situation, it is proposed an improvement, in the next 5 years, of the performance level up to a score of 729 points, with an increase of $34.3 \%$ and a gap of 250 points. The data for the axes of interest are presented below:

o for Citizens/Stakeholders Axis it is proposed to achieve an increase in the performance level of $36.3 \%$ or 87.5 points / promile. The main objectives pursued for this perspective are: modernization and efficiency of public transport, modernization of infrastructure, modernization of housing, reduction of environmental pollution, as well as, promotion and support of SMEs etc.

0 regarding the Financial Axis, it is recommended a performance improvement by $27.8 \%$ or 62.5 points / promile. Achieving this increase involves reducing costs by improving financial results and aligning fiscal policy with the overall strategic objectives of the organization.

o for the Internal Processes Axis, it is proposed to increase the performance level by $40 \%$, which means a difference of 50 points / promile. For this, it is necessary to focus efforts on the perception and satisfaction of the needs of the beneficiaries, while significantly improving partnerships and operational processes. Achieving the given objectives must be supported by the introduction of an integrated IT system that would facilitate the monitoring and control of activities.

o for the Organizational Learning Axis, an increase of the performance level is assumed by $44.5 \%$ or 50 points / promile. Primordial for this perspective is the development of an organizational structure that would facilitate the process of organizational alignment and efficient information management. Achieving the goals of the given objectives must be achieved in parallel with the efficient management of competencies, the development of human resources, leadership and the establishment of the organizational culture oriented towards excellence.

\section{Conclusions}

Although it is a concrete and objective basis for measurement, establishing a system of performance indicators in a public organization is a difficult task, as not all objectives can be quantified, often using benchmarking analyzes. Therefore, the introduction of this system must be coordinated with the creation of the appropriate legislative framework for implementation, as well as the development of a managerial capacity and human resources necessary for the successful implementation of the proposed objectives.

The performance audit of a public organization is also called "value for money audit" assesses the degree to which the audited entity's objectives and programs have been achieved or implemented, analyzing costs, risks, accuracy of achievement of objectives and resource consumption (including human resources); the "three E's" are checked: economy, effectiveness and efficiency (Dinga, Pop and Dimitriu, 2006)

Performance analysis involves tracking those „3e”'s:

o Evaluating the economy of the use of public funds, the extent to which it was ensured the minimization of the cost of resources used, without compromising the achievement in good conditions of the declared objectives, determining the achievement of the expected performance.

o Evaluating the efficiency of the relation between the obtained results and the resources used for the achievement of the objectives, is analyzed to what extent the allocated financial resources contributed to the maximization of the obtained results. 
o Evaluating the effectiveness of the degree of fulfillment of the objectives of the public organization, of the relationship between the desired impact and the actual impact achieved.

Control systems normally involve monitoring the performance of indicators proposed by projects and feedback for the results obtained (Lopez-Valeiras, Gomez-Conde and Naranjo-Gil, 2015; Dobre, 2007). This implies that performance auditing can establish the reliability and credibility of information on various aspects of performance. (Lonsdale, Wilkins and Ling, 2011)

Every organization must be aware that such approach can bring them benefits, both through creating a competitive advantage and through promoting a positive image and a good relation with all the partners, aspects that argue the inclusion of social responsibility in the development strategy. (Brezoi, 2018)

\section{References}

1. Armstrong, M., 2009. Performance management. Key strategies and practical guidelines, Kogan Page London and Philadelphia.

2. Brezoi, A.G., 2018. Ethics and Corporate Social Responsibility in the Current Geopolitical Context. Economic Insights - Trends and Challenges. 2018; VII (LXX) No. 2: 45 - 52.

3. Dinga, E., Pop, N. and Dimitriu, M., 2006. A performance audit procedure regarding the state of harmonization of Romania with the acquis communautaire in the field of financial control, Expert Publishing House, 2006, pp. 17-19.

4. Dobre, E., 2007. Project control and audit; Economic Publishing House: Bucharest, Romania, p.29.

5. Drozdowski, G. (2016). Emotional components of competence among executives: An empirical study. Економічний часопис-XXI, (11-12), 89-92.

6. Handler, H., Koebel, B., Reiss, Ph. and Schratzenstaller, M., 2004. The Size and Performance of Public Sector Activities in Europe, WIFO Working Papers, No. 246, Provided in Cooperation with: Austrian Institute of Economic Research (WIFO), Vienna. https://www.econstor.eu/bitstream/10419/128795/1/wp 246.pdf

7. Kaplan, R.S. and Norton, D.P., 2008. Mastering the management system, Harvard Business Review 86(1):62-77, February.

8. Lonsdale J., Wilkins, P. and Ling, T. Performance auditing. Contributing to accountability in democratic government, Edward Elgar Publishing: Cheltenham; UK, 2011.

9. Lopez-Valeiras, E., Gomez-Conde, J. and Naranjo-Gil, D., 2015. Sustainable Innovation, Management Accounting and Control Systems, and International Performance. Sustainability 2015, 7, 3479-3492.

10. Petrova, E., 2017. Genesis of Strategic Management, 1st edition, Elitsa Petrova \& bookboon.com, 2017, ISBN 978-87-403-1843-2.

11. Plumb, I., Androniceanu, A. and Abaluta, O. M., 2003. Public services management, ed. a 2-a, ASE Publishing House, Bucharest.

12. Popa, V., 2005. Management and performance measurement of the organization, Valahia University Press, Târgovişte.

13. Profiroiu, M., 2001. Management of public organizations, Economica Publishing House, Bucharest.

14. S. Praise, A., M.L. Kah, J., \& Raimi, L. (2020). Talent management practices and gender imbalance in institutions: impact on institutional performance. Dinasti International Journal of Education Management And Social Science, 1(5), 796-810.

15. Soboń, J., Drozdowski, G., \& Rogozińska-Mitrut, J., 2020. Preparation of human capital for changes: empirical study. In 11th International Scientific Conference „Business and Management 2020 ".

16. Waal, A.A. de, 2006. The Characteristics of High Performance Organizations. In A. Neely, M. Kennerley and A. Walters (Ed.), Performance Measurement and Management: Public and Private, Cranfield: Cranfield School of Management, pp. 203-210.

17. Waal, A.A. de, 2007. The Characteristics of a High Performance Organization, Business Strategy Series, August. 